\title{
Internalization of School Culture to Foster Awareness of Pancasila Values in Elementary School Students
}

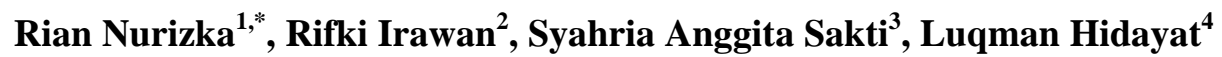 \\ ${ }^{1}$ Department of Elementary School Teacher Education, Faculty of Teacher Training and Education, Universitas PGRI Yogyakarta, \\ Yogyakarta, Indonesia \\ ${ }^{2}$ Department of English Language Education, Faculty of Teacher Training and Education, Universitas PGRI Yogyakarta, Yogyakarta, \\ Indonesia \\ ${ }^{3}$ Department of Early Childhood Teacher Education, Faculty of Teacher Training and Education, Universitas PGRI Yogyakarta, \\ Yogyakarta, Indonesia \\ ${ }^{4}$ Department of Special Education, Faculty of Teacher Training and Education, Universitas PGRI Yogyakarta, Yogyakarta, Indonesia
}

Received July 13, 2020; Revised August 7, 2020; Accepted September 17, 2020

\section{Cite This Paper in the following Citation Styles}

(a): [1] Rian Nurizka, Rifki Irawan, Syahria Anggita Sakti, Luqman Hidayat, "Internalization of School Culture to Foster Awareness of Pancasila Values in Elementary School Students," Universal Journal of Educational Research, Vol. 8, No. 10, pp. 4818 - 4825, 2020. DOI: 10.13189/ujer.2020.081053.

(b): Rian Nurizka, Rifki Irawan, Syahria Anggita Sakti, Luqman Hidayat (2020). Internalization of School Culture to Foster Awareness of Pancasila Values in Elementary School Students. Universal Journal of Educational Research, 8(10), 4818 - 4825. DOI: 10.13189/ujer.2020.081053.

Copyright $@ 2020$ by authors, all rights reserved. Authors agree that this article remains permanently open access under the terms of the Creative Commons Attribution License 4.0 International License

Abstract School culture is an integral part of the school that can affect the quality of behavior and can change students' cognitive patterns. The values of Pancasila as the ideology of the nation can be incorporated into school culture as a special feature of education in Indonesia. The importance of internalizing school culture as a process of habituation in growing student awareness must have the support of all school members. The purpose of this study is to foster student's awareness of the values of Pancasila as a view of the life of the Indonesian nation through the internalization of school culture. The research method used is descriptive qualitative. Data collection used in this study was field observations, interviews, and document analysis. Analysis of the data used is the display of data, data reduction, data presentation, and concluding. The results showed that the internalization of school culture to foster awareness of Pancasila values can be done through structuring the maintained and maintained physical environment of the school, structuring the school's social environment with social activities, structuring school personnel with the creation of security, order, and comfort of school residents, classroom management by applying the values of Pancasila in each learning process, the leadership of the principal by synergizing all components of the school, building a solid work spirit, improving school quality. The contribution of this research is that fostering awareness of the values of Pancasila must be done by all schools by optimizing the culture of the school they have.

Keywords School Culture, Habituation, Pancasila Values

\section{Introduction}

School culture is a supporting factor for school sustainability that affects the quality of human relations in education that determines the behavior patterns of school residents, especially teachers and students [1], which can be described in terms of the school ethos and social environment that consists of administrative and organizational structures that can be used in interactions to facilitate and limit learning process at school [2]. School culture can also be interpreted as the basis of actions taken by school residents in the form of assumptions and values that are implemented in school activities [3].

Likewise, the connection with school improvement is inseparable from school culture because it is included in an integral part that must be applied [4]. School culture itself is used as an important strategy in sustainable school 
improvement which consists of strong elements of school culture, namely the academic press, student support, trust and respect, optimism, and professional learning [5]. The application of school culture by the school community is used as an important role in the efforts of school stability and improvement, teacher professionalism, and teacher teaching patterns [6].

School leadership has an important role in creating a school culture and at the same time maintaining it [7]. Principals must make a cultural change by introducing and instilling school culture for their citizens who ultimately contribute positively to school organizations and create a strong school culture [8] [9]. Principals who have skills can create a change in school culture from negative to positive [10]. Towards a positive and participatory school culture, the principal is advised to take an instructional leadership approach by helping teachers in the collaborative process, instilling collective leadership, and communicating school vision together [11]. On the other hand, the quality that is carried out by professional teachers in the learning process also greatly contributes to the school culture towards a more collaborative direction [12]. Teachers can investigate and exchange knowledge together to develop learning material that can be used as a tool to promote school culture [13].

The internalization of school culture can be done by all school residents. Among them, teachers can be used as informants and sources of information about internalization when children enter [14]. In the context of internalization, it shows that the importance of environmental effects for children to respond to the social context occurs in their environment [15]. Besides, cultural competencies integrated into the school curriculum can help create awareness and instill values in students in their education and future [16]. The conceptualization of the internalization process can be seen from three different components but they are related to awareness, support, and internalization [17]. The importance of self-awareness is central to professional practice and the application of students' initial theories to practice [18]. To instill awareness in students, the way to do is to experience accompanied by direct practice with the surrounding environment which finally gets a deep awareness of the cognitive processes they get [19]. Therefore, the process of internalizing school culture requires a process of habituation carried out by the school.

The process of habituation through school culture in this study is to instill student awareness related to the values of Pancasila which is the ideology and outlook on life of the Indonesian nation. The process of habituation is the basis of learning manifested in development to assess cognitive functions that can be known from observations (behavior changes) and neurophysiological measurements (the brain's response to events) [20]. Habits and goals can also lead to decision making which is a fundamental process of adaptive behavior (Schreiner, et.al., 2020). As it is known that effective habituation can reflect the representation of long-term memory obtained from a learning process that is reinforced from specific repetitive stimuli [21].

Pancasila, as a way of life, ideology, and the basis of the Indonesian state, has values that are the result of the agreement of the founders of the Indonesian nation. These values are God, Humanity, Unity, Society, and Justice. Therefore, basic education to tertiary education has a very important role in instilling awareness in students of Pancasila values. Based on observations in the field of education, there was decadence in the actualization of Pancasila values due to the lack of student understanding in actualizing the values of Pancasila in life [22]. The results of library research conducted said the way to strengthen the values of the Pancasila in the era of disruption was that there was activity from the government and the support of all elements of society [23]. Things that can be done at school for example are the subjects of Civic Education imbued by Pancasila [24]. Efforts to revitalize the values of Pancasila can also be made to be brought to life in Indonesian society [25]. This is similar to what has conveyed Kalis and Ometto that habit is a context sign that is used in the long term which is learned directly to achieve the goal [26]. So that with the process of habituation and support of all elements of society, the values of Pancasila can be instilled in the younger generation.

The Pancasila paradigm is an integrated whole that is interconnected between the Pancasila precepts [27]. Pancasila is a revolutionary concept that advances civilization and as a shaper of national character and identity that can be used as a medium of acculturation in various partial thoughts [28]. Pancasila, aside from being an ideology of the nation, is also used as the foundation of education in Indonesia by the development of eighteen character values by the Ministry of Education and Culture. These values are then further developed by integrating into the written curriculum, unwritten curriculum, co-curriculum activities, and extracurricular activities which means they can be carried out through classroom learning processes, assignments outside the classroom, and manifested in school rules [29]. Efforts to preserve the values of Pancasila in education in Indonesia as a form of deep love for the nation, as well as to realize the effectiveness of Pancasila which was born from traditional values that make it a major contemporary factor in maintaining the unity and diversity in Indonesia [30].

\section{Materials and Method}

\subsection{Research Design}

This type of research is descriptive qualitative. This research is to describe the real situation in the field with data in the form of words related to the internalization of school culture in instilling an awareness of Pancasila 
values in students. The location of this research is SD Negeri 02 Batuagung, Tegal Regency, Central Java Province, Indonesia. The study was conducted from May to October 2019.

\subsection{Population and Sample}

Collecting data in this study using purposive and snowball techniques. The sample was chosen because it has information objectively about the research topic and is part of the activities on this research topic. The sample in this study is the Principal, 6 Teachers, and 9 Students. The school principal was chosen as a key informant providing important information about internalizing school culture to instill awareness of the values of Pancasila. The teacher is chosen to get information related to the learning process and instilling the values of Pancasila in the classroom and outside the classroom. Students are selected mainly from grades 4,5 , and 6 with a sample of 9 students to find out what school culture information has been invested in them while at school. The following is demographic information about the respondents in the study.

Table 1. Demographic Statistics of Research Respondents

\begin{tabular}{|c|c|c|}
\hline Demographics & Frequency & Percent $\%$ \\
\hline Gender Principal and Teacher & & \\
\hline Male & 5 & 71 \\
\hline Female & 2 & 29 \\
\hline Age in Years & & \\
\hline $30-35$ & 1 & 14 \\
\hline $36-40$ & 3 & 43 \\
\hline $45-50$ & 1 & 14 \\
\hline $50-55$ & 2 & 29 \\
\hline Qualification & & \\
\hline Bachelor's Degree & 7 & 100 \\
\hline Master Degree & 0 & 0 \\
\hline Student gender & & \\
\hline Male & 5 & 56 \\
\hline Female & 4 & 44 \\
\hline Age in Years & & \\
\hline $5-10$ & 2 & 22 \\
\hline $10-15$ & 7 & 78 \\
\hline
\end{tabular}

\subsection{Instrument and Data Analysis}

Data collection instruments used in this study used observation sheets, interview guides, and documentation sheets. Observation sheets are used to collect observational data, interview guidelines to ask informants about how to internalize school culture to instill awareness of Pancasila values, and documentation sheets are used to obtain research supporting data. Data collection is done by triangulation by combining several techniques simultaneously. Analysis of the data used in research is data collection, data reduction, data presentation, and concluding.

\section{Result and Discussion}

Based on the results of the research that has been done, this section will explain the question of internalizing the culture of the school in instilling an awareness of the values of Pancasila to students. Questions developed from opinions Kaelan mentions the process of internalizing Pancasila values to instill awareness in students by knowledge, awareness, obedience, will ability, character and conscience, strategy, and method [31]. From this opinion, the research instrument was further developed with the school culture as an internalization process that can be carried out by schools to instill awareness among students. School culture developed is: i) structuring the school's physical environment, ii) structuring the school's social environment, iii) structuring school personnel, iv) classroom management, and v) school principal leadership [32]. The following is a description of what has been done from the research process from data collection, analysis process, and interpretation.

\section{i). Structuring the School's Physical Environment}

The interview process conducted with the Principal regarding the arrangement of the school's physical environment to foster awareness of the values of Pancasila, obtained the result that directing all school members in managing the physical environment owned by the school so that it is always well guarded because it is the main means to instill awareness in students such as places of worship as a form of planting the value of God, classrooms, sports facilities, school gardens, reading rooms, and other supporting facilities as part of a tool to instill the values of Pancasila because of their function in the educational process. This is in line with the opinion that says that the school's physical environment such as facilities and infrastructure can give support to students in their activities at school [33].

The school environment can have a significant impact on children's behavior [34]. This is consistent with the results of observations made that schools always pay attention to assets and facilities that are owned as a process to provide comfort to students in the learning process at school is also evidenced by the predicate Adiwiyata school. It is more emphasized in instilling the value of Pancasila namely God that teachers and principals provide examples of how to prioritize worship even in the learning process.

Growing awareness of the values of Pancasila can also be seen from the clean cultural activities carried out by all school members, especially every Friday. The results of interviews with other respondents who were given the code T1-T6 (for teacher code) related to how schools optimize the physical environment for the process of growing awareness of Pancasila values obtained the following data. 
Table 2. Teacher responses about the physical environment of the school

\begin{tabular}{|c|c|c|c|c|c|c|}
\hline Question & $\mathrm{T} 1$ & $\mathrm{~T} 2$ & T3 & $\mathrm{T} 4$ & T5 & T6 \\
\hline $\begin{array}{l}\text { How to optimize } \\
\text { the school's } \\
\text { physical } \\
\text { environment } \\
\text { concerning } \\
\text { growing } \\
\text { awareness of } \\
\text { Pancasila values } \\
\text { in students? }\end{array}$ & $\begin{array}{l}\text { Together with } \\
\text { students doing } \\
\text { class cleanliness } \\
\text { and places of } \\
\text { worship } \\
\text { because of the } \\
\text { environment } \\
\text { provides } \\
\text { comfort for } \\
\text { learning. }\end{array}$ & $\begin{array}{l}\text { Invite students } \\
\text { not to litter and } \\
\text { put up the best } \\
\text { work of } \\
\text { students on the } \\
\text { walls of the } \\
\text { school. }\end{array}$ & $\begin{array}{l}\text { As a teacher to } \\
\text { instill the value of } \\
\text { God by inviting } \\
\text { students to } \\
\text { worship in places } \\
\text { of worship. }\end{array}$ & $\begin{array}{l}\text { Reading } \\
\text { room } \\
\text { owned by } \\
\text { the school } \\
\text { to teach } \\
\text { togetherness } \\
\text { between } \\
\text { students }\end{array}$ & $\begin{array}{l}\text { Put up positive } \\
\text { sentences on the } \\
\text { walls of the } \\
\text { school so they } \\
\text { can be read and } \\
\text { understood and } \\
\text { then } \\
\text { implemented by } \\
\text { students. }\end{array}$ & $\begin{array}{l}\text { School facilities } \\
\text { are always } \\
\text { prioritized for the } \\
\text { progress and } \\
\text { learning process } \\
\text { of students, } \\
\text { especially } \\
\text { fostering the spirit } \\
\text { of Pancasila } \\
\text { because it is the } \\
\text { ideology of the } \\
\text { nation. }\end{array}$ \\
\hline
\end{tabular}

What is conveyed by the teachers shows that the physical environment that is maintained and well maintained will encourage students to always learn. School design and school policy must adjust the needs of students, especially for the playground because the environment can improve students' personal [35]. Associated with the relationship with growing awareness of Pancasila values, it can be seen that Pancasila values are integrated into every process that exists in schools with the support of a good physical environment for their growth. From the results of interviews with students, it shows that a good physical school environment can help the process of introducing Pancasila values and make students more enthusiastic about the learning process.

\section{ii). Structuring the School's Social Environment}

For the structuring of the school's social environment, an interview process was carried out with the school principal with the results that showed that the school was very appreciative of every step taken to create a good school social environment, as evidenced by the existence of school safety that was guarded jointly with all school residents, visiting homes for students who are sick or hold social activities, there are social activities with Friday charity activities, schedules for recreation together, invites parents of students in deliberations for school progress, and cooperation activities as a form of maintaining the school's social environment remains conducive. The social environment of the school such as the support of teachers and peers can provide support to students in their activities at school [36]. This is very interesting to be used as a process of growing awareness of Pancasila values through the process of structuring the school's social environment because students will see how the school provides a good social environment for all students. Reflections on divine values, human values, values of unity, values of society, and values of justice from the values of Pancasila can be well illustrated by the processes that exist in every school activity.

The observations made also showed results that were very much in line with what the school principal said. Growing student awareness through a good social environment will affect their lives in association with friends and the wider community. Another interview is to students with a code S1-S9 (code for students) to ask how the school provides a social environment to foster awareness of the values of Pancasila, with the following results. 
Table 3. Student responses about the social environment of the school

\begin{tabular}{|c|c|c|c|c|c|}
\hline Question & $\mathrm{S} 1$ & $\mathrm{~S} 2$ & S3 & $\mathrm{S} 4$ & S5 \\
\hline \multirow{3}{*}{$\begin{array}{l}\text { How do schools } \\
\text { provide a social } \\
\text { environment as an } \\
\text { effort to foster } \\
\text { awareness of } \\
\text { Pancasila values? }\end{array}$} & $\begin{array}{l}\text { There is a good } \\
\text { relationship with } \\
\text { the parents of } \\
\text { students by visiting } \\
\text { if there are students } \\
\text { who are sick or } \\
\text { social activities. }\end{array}$ & $\begin{array}{c}\text { Teachers, } \\
\text { employees, and } \\
\text { school guards are } \\
\text { kind to students } \\
\text { even though there } \\
\text { are naughty } \\
\text { students. }\end{array}$ & $\begin{array}{l}\text { High solidarity is } \\
\text { shown to students } \\
\text { by doing } \\
\text { community service } \\
\text { together and } \\
\text { cooperation }\end{array}$ & $\begin{array}{l}\text { Do not discriminate } \\
\text { between students in } \\
\text { economics or } \\
\text { intelligence. }\end{array}$ & $\begin{array}{l}\text { Putting up student } \\
\text { work on the walls } \\
\text { of the school } \\
\text { makes others try to } \\
\text { be better. }\end{array}$ \\
\hline & S6 & S7 & S8 & S9 & \\
\hline & $\begin{array}{l}\text { Teach students to } \\
\text { always worship and } \\
\text { be friends with } \\
\text { others and the } \\
\text { environment }\end{array}$ & $\begin{array}{l}\text { The school visited } \\
\text { the homes of sick } \\
\text { students or parents } \\
\text { of students who } \\
\text { died }\end{array}$ & $\begin{array}{l}\text { A good teacher } \\
\text { always gives advice } \\
\text { when making a } \\
\text { mistake }\end{array}$ & $\begin{array}{l}\text { The school does not } \\
\text { differentiate } \\
\text { between groups or } \\
\text { students' } \\
\text { backgrounds. }\end{array}$ & \\
\hline
\end{tabular}

The table shows that from the condition of the students also illustrates that to foster awareness about the values of Pancasila as a value of goodness believed by the Indonesian people as an ideology can be demonstrated by optimizing the social environment of a good school. The school environment can form self-concepts and social networks for students which can be utilized to encourage healthy development [37].

\section{iii). Arrangement of School Personnel}

School personnel consists of all school members, namely the principal, teachers, students, employees or school administration staff, and school security. Structuring school personnel as part of the school culture associated with growing awareness of Pancasila values can be used as a tool to remind each other as part of the school community. From the results of interviews with the principal as the holder of school, authority shows that the arrangement of school personnel is intended to create school security both arising from inside the school or outside the school such as to comply with school rules, advise and give sanctions to anyone who violates the rules and damage the image of the school, on the other hand, structuring also on aspects of social welfare both students and teachers and employees, for example, is affected by the disaster.

\section{iv). Classroom Management}

The results of interviews with the teacher about the question of how is classroom management conducted to foster awareness of the values of Pancasila as a student learning process? indicated by the following results.

Table 4. Teacher responses to classroom management

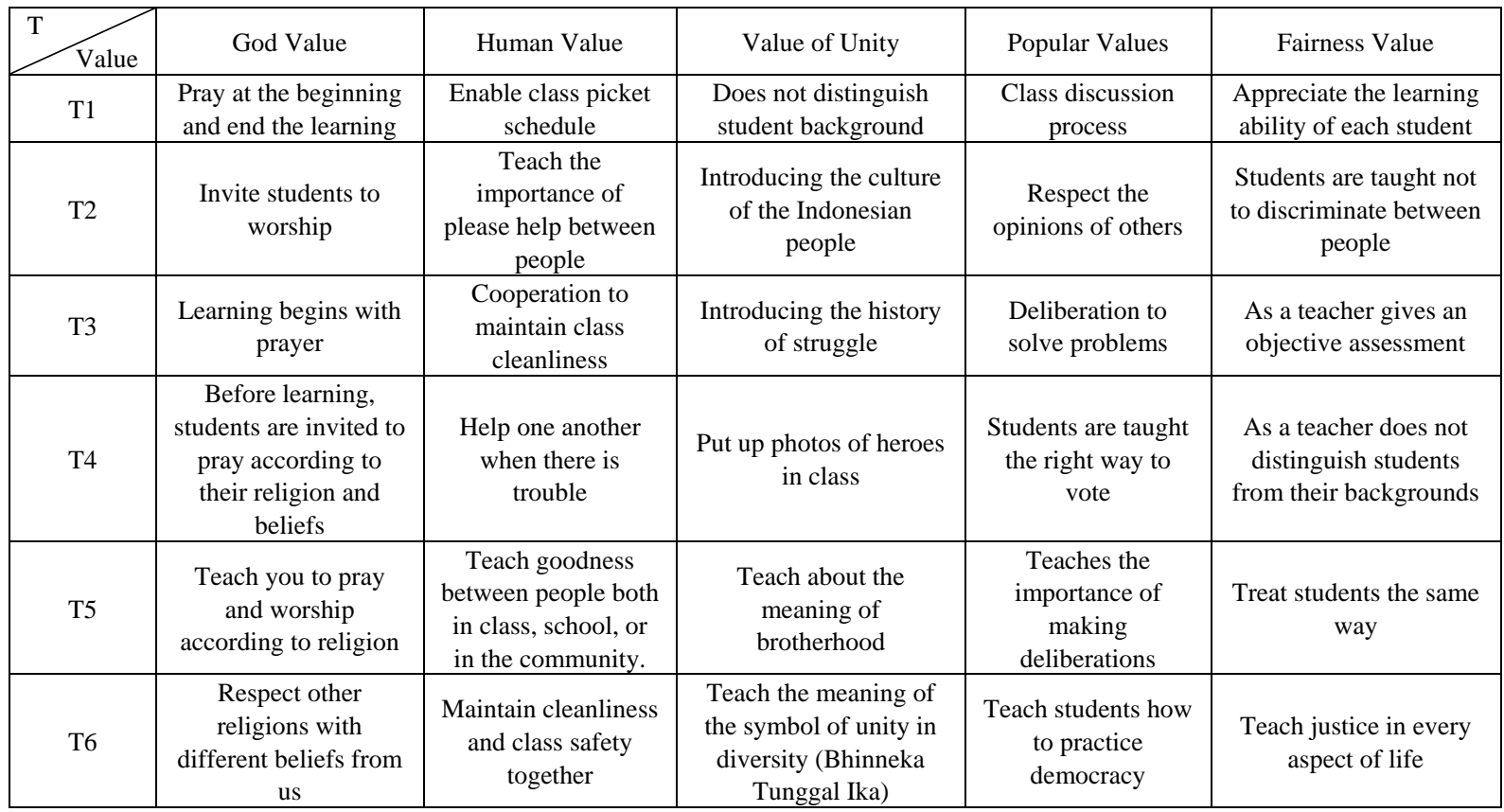


From this table, it can be explained that the values of Pancasila can be instilled in students from the learning process carried out by the teacher with different circumstances and activities. But for the divine value, almost all teachers do prayer activities at the beginning of learning and the end of learning. While other values are almost varied concerning examples of activities that can foster awareness of Pancasila values through classroom management. From the results of other data, collection observations were found that classroom management is indeed done well by the teacher who is the advice and direction of the principal to always instill student awareness of the importance of the noble values of Pancasila.

\section{v). Principal's Leadership}

School culture will be created well if there is a good headmaster's leadership. Principal's leadership style by building a constant closeness with students, while leadership techniques by basing Pancasila values to become good students [38]. Related to growing awareness of Pancasila values, from interviews with principals, several aspects need to be considered in shaping good school culture, including the need for synergy with all school components that can be done by optimizing the use of communication media with teachers and parents of students. In line with the results of research which states that principals and communities always enhance collaboration using digital media such as WhatsApp, telegram, and other methods [39]. Other results include an increase in the quality or achievement of the school, holding activities that support the professionalism of teachers, building a solid work spirit of all school components, and the principle being used as a motivator, facilitator, and role model for all school members. The headmaster as a whole understands the tasks of developing learning practices and for teacher supervision by monitoring and evaluating their teaching and knowledge [40]. The principal's answer suggests that to form a good school culture, it must go through a difficult process. The observations made also show that the principal is an example to all teachers and students because of their devotion, social life, solidarity, prioritizing deliberation, fairness for all, and discipline in all school affairs. Then in terms of behavior and hard work and the enthusiasm shown can provide a positive impact on teachers and students. This is where the role of the principal can foster awareness of the values of Pancasila not only for students but also for teachers.

\section{Conclusions}

Based on the results of research related to the internalization of school culture to foster the awareness of the values of Pancasila in elementary school students, it can be concluded that the school culture developed is as follows.

1. Structuring the maintained and well-maintained school physical environment that can provide comfort in the process of growing student's awareness about the values of Pancasila

2. Structuring the school's social environment with social activities carried out by all school residents.

3. Structuring school personnel with the creation of security, order, and convenience of school residents

4. Class management by applying Pancasila values in each learning process.

5. Principal's leadership by synergizing all components of the school, building a solid work spirit and improving school quality.

\section{Acknowledgments}

The researcher would like to thank LPPM Universitas PGRI Yogyakarta for the assistance funds provided to complete this research.

\section{REFERENCES}

[1] Ümit Kalkan, Fahriye Altınay Aksal, Zehra Altınay Gazi, Ramazan Atasoy, and G. D. (2020). The Relationship Between School Administrators' Leadership Styles, School Culture, and Organizational Image. SAGE Open, 10(1). https://doi.org/10.1177/2158244020902081.

[2] Avalos, B. (2011). Teacher professional development in Teaching and Teacher Education over ten years. Teaching and Teacher Education, 27(1), 10-20. https://doi.org/10.10 16/j.tate.2010.08.007.

[3] Milan Pol, Lenka Hloušková, Petr Novotný, Eva Václavíková, J. Z., \& Introduction. (2005). School culture as an object of research. New Educational Review, (1963), $147-165$.

[4] Seashore Louis, K., \& Lee, M. (2016). Teachers' capacity for organizational learning: the effects of school culture and context. School Effectiveness and School Improvement, 27(4), 534-556. https://doi.org/10.1080/09243453.2016.11 89437

[5] Lee, M., \& Louis, K. S. (2019). Mapping a strong school culture and linking it to sustainable school improvement. Teaching and Teacher Education. https://doi.org/10.1016/j. tate.2019.02.001.

[6] Deal, T., \& Peterson, K. (2016). Shaping school culture (3rd ed.). Jossey-Bass.

[7] Sperandio, J., \& Kong, P. A. (2018). Forging professional learning communities: the role of external agency. International Journal of Leadership in Education, 21(1), 80-94. https://doi.org/10.1080/13603124.2016.1182646

[8] Coleman, M. (2020). Leading the change to establish a whole-school nurturing culture. Emotional and Behavioural Difficulties, 25(1), 68-79. https://doi.org/10.1080/13632752 


\section{.2019 .1682244}

[9] Ümit Kalkan, Fahriye Altınay Aksal, Zehra Altınay Gazi, Ramazan Atasoy, and G. D. (2020). The Relationship Between School Administrators' Leadership Styles, School Culture, and Organizational Image. SAGE Open, 10(1). https://doi.org/10.1177/2158244020902081.

[10] Deal, T., \& Peterson, K. (2016). Shaping school culture (3rd ed.). Jossey-Bass.

[11] Adel Zahed-Babelan, Ghodratollah Koulaei, M. M. in A. R. S. (2019). Instructional leadership effects on teachers' work engagement: Roles of school culture, empowerment, and job characteristics. Center for Educational Policy Studies Journal, 9(3), 137-156. https://doi.org/10.26529/cepsj.181.

[12] Patton, K., \& Parker, M. (2017). Teacher education communities of practice: More than a culture of collaboration. Teaching and Teacher Education, 67, 351360. https://doi.org/10.1016/j.tate.2017.06.013.

[13] Schipper, T. M., de Vries, S., Goei, S. L., \& van Veen, K. (2020). Promoting a professional school culture through lesson study? An examination of school culture, school conditions, and teacher self-efficacy. Professional Development in Education, 46(1), 112-129. https://doi.org/10.1080/19415257.2019.1634627

[14] Navarro, M. C., Orri, M., Nagin, D., Tremblay, R. E., Oncioiu, S. I., Ahun, M. N., ... Côté, S. M. (2020). Adolescent internalizing symptoms: The importance of multi-informant assessments in childhood. Journal of Affective Disorders. https://doi.org/10.1016/j.jad.2020.01.1 06.

[15] Humphrey, J. L., \& Root, E. D. (2017). Spatio-temporal neighborhood impacts on internalizing and externalizing behaviors in U.S. elementary school children: Effect modification by child and family socio-demographics. Social Science and Medicine, 180, 52-61. https://doi.org/10.1016/j.socscimed.2017.03.014

[16] Villagran, M. A. L., \& Hawamdeh, S. (2020). Cultural competence in LIS education: case study of United States ranked schools. Multicultural Education Review, 00(00), 120. https://doi.org/10.1080/2005615X.2020.1756091.

[17] Vartanian, L. R., \& Hayward, L. E. (2020). Dimensions of internalization relevant to the identity disruption model of body dissatisfaction. Body Image, 32, 1-4. https://doi.org/10.1016/j.bodyim.2019.10.008.

[18] Blakemore, T., \& Agllias, K. (2019). Student Reflections on Vulnerability and Self-awareness in a Social Work Skills Course. Australian Social Work, 72(1), 21-33. https://doi.org/10.1080/0312407X.2018.1516793.

[19] Krusberg, Z., \& Ward, M. (2018). Classical physics and human embodiment: The role of contemplative practice in integrating formal theory and personal experience in the undergraduate physics curriculum. 1-26. Retrieved from http://arxiv.org/abs/1804.05748.

[20] Hartkopf, J., Moser, J., Schleger, F., Preissl, H., \& Keune, J. (2019). Changes in event-related brain responses and habituation during child development - A systematic literature review. Clinical Neurophysiology, 130(12), 22382254. https://doi.org/10.1016/j.clinph.2019.08.029.
[21] Schreiner, D. C., Renteria, R., \& Gremel, C. M. (2020). Fractionating the all-or-nothing definition of goal-directed and habitual decision-making. Journal of Neuroscience Research, 98(6), 998-1006. https://doi.org/10.1002/jnr.245 45.

[22] Rika, E., \& Huda, S. (2019). Actualization of Pancasila Values (Indonesian Ideology) in Majelis Taklim Organization. Al-Hayat: Journal of Islamic Education (AJIE), Volume 3(1), 68-81. https://doi.org/https://doi.org/1 $0.35723 /$ ajie.v3i1.46.

[23] Lonto, A. L., \& Pangalila, T. (2019). The existence of Pancasila Values in the Disrupted Era. 335(ICESSHum), 145-149. https://doi.org/10.2991/icesshum-19.2019.23.

[24] Dewantara, J. A., Suhendar, I. F., Rosyid, R., \& Atmaja, T. S. (2019). Pancasila as Ideology and Characteristics Civic Education in Indonesia. International Journal for Educational and Vocational Studies, 1(5), 400-405. https://doi.org/10.29103/ijevs.v1i5.1617.

[25] Latief, A., Nadir, M., Pangalila, T., Lonto, A. L., Suyanto, T., \& Warsono, M. (2020). Revitalizing the Value of Pancasila in the Development of the Character of Indonesian Citizens. 226(Icss), 923-926. https://doi.org/10.2991/icss-18.2018.19 1 .

[26] Kalis, A., \& Ometto, D. (2019). An Anscombean Perspective on Habitual Action. Topoi, (0123456789). https://doi.org/10.1007/s11245-019-09651-8.

[27] Salampessy, Z., Triyuwono, I., Irianto, G., \& Hariadi, B. (2018). Pancasila paradigm: Methodology of wawasan nusantara for accounting of pancasila. Australasian Accounting, Business and Finance Journal, 12(1), 102-117. https://doi.org/10.14453/aabfj.v12i1.7.

[28] Amir, S. (2013). Pancasila as Integration Philosophy of Education And National Character. International Journal of Scientific and Technology Research, 2(1), 54-57. Retrieved from www.ijstr.org.

[29] Suyatno, Jumintono, Dholina Inang Pambudi, Asih Mardati, Wantini. (2019). International Journal of Instruction. 12(1), 607-624. Retrieved from https://files.eric.ed.gov/fulltext/EJ 1201358.pdf.

[30] Fitch, R. M., Webb, S. A., \& Fitch, R. M. (1989). Cultural Immersion in Indonesia through Pancasila : State Ideology. The Journal of Educational Thought (JET, 23(1), 44-51. https://doi.org/10.2307/23768636.

[31] Kaelan. (2016). Pendidikan Pancasila. Yogyakarta: Paradigma.

[32] Daryanto. (2015). Pengelolaan Budaya dan Iklim Sekolah, Yogyakarta: Gava Media.

[33] Chu, T. L. (Alan), Zhang, T., Thomas, K. T., Zhang, X., \& Gu, X. (2020). School environments predict Hispanic children's physical education related outcomes through basic psychological need satisfaction. Learning and Individual Differences, 80(December 2019), 101844. https://doi.org/10.1016/j.lindif.2020.101844.

[34] Rasyidah, G., \& Wafa, S. W. (2020). A quantitative assessment of school environment as viewed by teachers. Heliyon, 6(6), e04059. https://doi.org/10.1016/j.heliyon.202 $0 . \mathrm{e} 04059$. 
[35] Aminpour, F., Bishop, K., \& Corkery, L. (2020). The hidden value of in-between spaces for children's self-directed play within outdoor school environments. Landscape and Urban Planning, 194(March 2019), 103683. https://doi.org/10.101 6/j.landurbplan.2019.103683.

[36] Chu, T. L. (Alan), Zhang, T., Thomas, K. T., Zhang, X., \& Gu, X. (2020). School environments predict Hispanic children's physical education related outcomes through basic psychological need satisfaction. Learning and Individual Differences, 80(December 2019), 101844. https://doi.org/10.1016/j.lindif.2020.101844.

[37] Dudovitz, R. N., Perez-Aguilar, G., Kim, G., Wong, M. D., \& Chung, P. J. (2017). How Urban Youth Perceive Relationships Among School Environments, Social Networks, Self-Concept, and Substance Use. Academic Pediatrics, 17(2), 161-167. https://doi.org/10.1016/j.acap.2 016.10.007.
[38] Fitriati, R., Romdana, R., \& Rosyidi, U. (2014). The Practice of the School Principal's Leadership in Sekolah Indonesia Kuala Lumpur (SIKL): The Study of Leadership Styles and Techniques with Cognitive Mapping Approach. Procedia Social and Behavioral Sciences, 115(Iicies 2013), 258-268. https://doi.org/10.1016/j.sbspro.2014.02.434.

[39] Yusof, M. R., Dayang Rafidah Syariff, M. F., Yaakob, M. F. M., Don, Y., \& Ibrahim. (2020). Digital communication: Priorities in the relationship of principal leadership and collaborative community at Malaysian School. Universal Journal of Educational Research, 8(4), 1149-1154. https://doi.org/10.13189/ujer.2020.080404.

[40] Khan, A. A., Asimiran, S., Kadir, S. A., \& Basri, R. (2020). Principals' instructional leadership practices in Pakistan elementary schools: Perceptions and implications. Universal Journal of Educational Research, 8(1 A), 16-23. https://doi.org/10.13189/ujer.2020.081303. 